\title{
Logical Empiricism between Pragmatism and Neopragmatism
}

\section{Pihlström, Sami Johannes}

Routledge

2018

Pihlström , S J 2018 , Logical Empiricism between Pragmatism and Neopragmatism . in M Baghramian \& S Marchetti (eds), Pragmatism and the European Traditions : Encounters with Analytic Philosophy and Phenomenology before the Great Divide ., 11, Routledge Studies in American Philosophy, Routledge, Abingdon , pp. 251-268 .

http://hdl.handle.net/10138/302532

acceptedVersion

Downloaded from Helda, University of Helsinki institutional repository.

This is an electronic reprint of the original article.

This reprint may differ from the original in pagination and typographic detail.

Please cite the original version. 


\section{LOGICAL EMPIRICISM BETWEEN PRAGMATISM AND NEOPRAGMATISM Sami Pihlström}

Helsinki Collegium for Advanced Studies

E-mail: sami.pihlstrom@ helsinki.fi

\section{Introduction}

Both logical empiricism and pragmatism have been regarded as "philosophical revolutions", and both went through crucial development and transformation during the period this book focuses on, 1895-1935. This essay can by no means exhaustively analyze these developments. However, I will examine some ways in which more recent neopragmatism is rooted in the "revolution" of those years, as well as some neglected pragmatism-related trends in logical empiricism.

The Americanization of originally European analytic philosophy, beginning with the rise of Nazism in Europe, has been described as a move "from the Vienna Circle to Harvard Square" (Holton 1993). There are, indeed, significant links between logical empiricism ${ }^{1}$ and American pragmatism; these links can also be argued to have been influential, albeit often implicitly, in the emergence of what is today known as neopragmatism. ${ }^{2}$ In the United States, C.I. Lewis, Ernest Nagel, and W.V. Quine, among others, played an important role as mediators between these philosophical schools. ${ }^{3}$ Another interesting mediating figure - some decades earlier - between pragmatism and early analytic philosophy was Frank Ramsey, who could have changed the history of twentieth century philosophy by truly developing a synthesis of these philosophies, had he lived longer. ${ }^{4}$ Charles Morris's "pragmatic empiricism" was yet another milestone between Vienna and America; Morris argued for the complementarity and even convergence of pragmatism and logical empiricism throughout the 1930s (see Morris 1937, 1938, 1963; cf. Carnap 1963).

\footnotetext{
${ }^{1}$ I will speak of "logical empiricism" instead of "logical positivism", unless there is a reason to be more specific. By "logical empiricism" I understand the somewhat broader set of doctrines, or the slightly more inclusive approach, that survived the collapse of the Vienna Circle (and thus the collapse of logical positivism in a strict sense).

2 For the distinction between "neopragmatism" and "new pragmatism" (which need not have any explicit relation to the historical tradition of pragmatism), see Misak (2007).

${ }^{3}$ For detailed examinations of the concept of the a priori in logical empiricism, see Friedman (2007) and Mormann (2012). For discussions of Q uine's problematic place in the pragmatist tradition, see Koskinen and Pihlström (2006) and Sinclair (2013). In this paper, I will have to mostly ignore both Lewis and Quine.

${ }^{4}$ For instance, Ramsey's 1927 essay, "Facts and Propositions", articulates a pragmatic understanding of the meaning of a proposition in terms of the conduct that would result from asserting the proposition. This is, clearly, a position reminiscent of Charles Peirce's and William James's views on meaning. See also Cheryl Misak's essay in this volume.
} 
The dialogue between pragmatism and logical empiricism was not restricted to the work of mediating thinkers like Morris and Nagel who later became somewhat marginalized. Even the giants of the two movements entered into a dialogue in the early 1930s. The mutual visits across the Atlantic in early 1930s and the preparations for the 1934 International Congress for Philosophy in Prague (Limbeck-Lilineau 2012), as well as Carnap's and John Dewey's exchange of views on meaning and the nature of philosophical problems in Philosophy of Science in 1934 are examples of this (cf. Shook 1998, 462), as is Hans Reichenbach's (1939) realistic criticism of Dewey's instrumentalist philosophy of science. In the late 1930s, D ewey contributed to the International Encyclopedia of Unified Scienœe, a project launched by the Vienna Circle philosophers. ${ }^{5}$

Leading scholars of logical empiricism, e.g., Thomas Uebel (1992, 1996, 2007) and Alan Richardson (1998), have investigated the relations between logical empiricism and twentieth century naturalism and pragmatism in great detail, drawing attention, for instance, to how "Quinean" - naturalistic and anti-foundationalist - some of Otto Neurath's views were decades before the emergence of Quine's philosophy (cf. Richardson and Uebel 2007). As Richard Creath $(2007,335)$ observes, Quine's caricature of Carnap's conventionalism - as something allegedly entirely different from the pragmatic naturalism Quine himself advanced - has unfortunately been "endlessly repeated by others". Gradually this picture has become more nuanced, to the extent that it is a commonplace today to appreciate the common ideas shared not only by Q uine and Carnap but generally by pragmatism and logical empiricism. Therefore, as Cheryl Misak (2013, chapter 9) also argues, the thesis that pragmatism, which had flourished in the US from James's popular philosophy in the early 1900s until D ewey's late work between the world wars, was "eclipsed" by logical empiricism (and later by analytic philosophy) is problematic, if not outright mistaken. Not only does the pragmatic maxim, which urges us to examine the meaning of our concepts in terms of the potential practical results of their objects, ${ }^{6}$ resemble the logical empiricists' verificationist theory of meaning, according to which the meaning of a sentence is reducible to its method of verification (and, indeed, only empirically verifiable sentences are meaningful); also the rejection of unempirical metaphysical speculation, as well as the intimate link between scientific progress and social progress, can be regarded as points of contact between the two traditions. Clearly both the pragmatists and the logical empiricists, at least after the Vienna Circle philosophers' arrival in the United States, understood this. As Misak

\footnotetext{
${ }^{5}$ For more details and exact references (including archival documentation based on Carnap's, Schlick's, Neurath's and others' papers and correspondence), see Limbeck-Lilineau (2012). For Dewey's E ncyclopedia contributions, see his (1938) and (1939).

6 On the pragmatic maxim and its different versions and applications, see, e.g., Pihlström (ed.) (2011).
} 
concludes: "The similarities between pragmatism and logical empiricism were there (and where recognized) from the beginning." (Ibid., 175.)

Furthermore, there seems to be a growing consensus about the fact that it was the internal critical development - rather than any external pressure - of the Vienna Circle and of the logical empiricism following its key members' emigration in the 1930s that led to positions relatively close to the naturalistic, fallibilistic pragmatism that had been developed by D ewey and philosophers like Nagel, Lewis, and Morris. Hence, the contacts between the two traditions that were established in the early 1930s may not have played any crucial role in this rapprochement.? The Vienna Circle philosophers might have arrived at their somewhat more relaxed stance - in comparison to the verificationism many of them had advanced in the 1920s and early 1930s even if they had never encountered D ewey and the other pragmatists.

Given this state-of-the-art in the scholarship on the history of pragmatism and logical empiricism, there is little to be added to the historical picture of what was going on between 1895 and 1935; I hope, however, to provide a distinctive perspective on these issues by taking seriously not just the relations between logical empiricism and pragmatism but especially between these two and neopragmatism. I will focus on the philosophical background of neopragmatism rather than on the pragmatist tradition as a whole (or logical empiricism as such), ${ }^{8}$ seeking to philosophically illuminate some ways in which neopragmatism grows out of the pragmatism - logical empiricism dialogue. I will not discuss the above-mentioned mediators (e.g., Nagel, Lewis, or Morris); my main focus in section 2 below will be on the leading neopragmatist Hilary Putnam's residual Carnapianism and on a critical discussion of the status of metaphysics in pragmatism and neopragmatism. It can be shown that while neopragmatism has successfully moved beyond several logical-empiricist doctrines, such as the dichotomies between the analytic and synthetic as well as between fact and value (not to forget neopragmatists' general rejection of the scientism we associate with logical empiricism), neopragmatism remains committed to other important logical-empiricist ideas, especially the critique of metaphysics. This is still clearly manifested, e.g., in Putnam's rejection of metaphysical realism as well as his reluctance to formulate his views on the fact-value entanglement in metaphysical terms (cf.

\footnotetext{
${ }^{7}$ See Limbeck-Lilineau (2012). The international philosophy congress in Prague in 1934 was a crucial step in the emergence of the mutual recognition of pragmatism and logical empiricism, but as Limbeck-Lilineau concludes, "neither the [logical empiricists'] liberalization of the meaning criterion, nor the introduction of dispositional concepts was initiated through the contact with pragmatism" (107).

${ }^{8}$ Charles Morris used the term "neopragmatism" already in 1928 (thanks are due to Christoph Limbeck-Lilineau for this important information).
} 
Pihlström 2010). ${ }^{9}$ Finally, I will in section 3 make an excursus to the legacy of a rather forgotten logical empiricist, Eino Kaila, arguing that scientific realism is a (or even the) major issue uniting the key philosophical concerns of pragmatism and logical empiricism.

Insofar as we want to speak about "philosophical revolutions" in relation to pragmatism and logical empiricism, we may say that while both approaches were in their own ways revolutionary attempts to set aside traditional non-empirical speculation, neopragmatism still has not fully recovered from the failure of this attempted revolution. A new revolution is needed to make neopragmatism more hospitable to metaphysics. By this I do not mean that the pragmatists should just follow the "metaphysical turn" of recent analytic philosophy; pragmatist metaphysics should, rather, seek to - revolutionarily? - transform our understanding of metaphysics itself (cf. Pihlström 2009).

\section{Linguistic frameworks and conceptual relativity: Camap and neopragmatism}

The encounter pragmatism had with logical empiricism can be explored by recapitulating some familiar points about Carnap's doctrine of linguistic frameworks. This discussion will illuminate the role of logical empiricism as a source of insights for neopragmatism especially because of the inspiration Putnam drew from logical empiricism, notably his teachers Carnap and Reichenbach. Even though Putnam mostly worked with Carnap on inductive logic instead of, say, the realism issue, this background is rather obvious when we consider the striking similarity between Putnam's (1981, 1990) "internal realism" and Carnap's theory of linguistic frameworks and internal vs. external questions of existence. ${ }^{10}$

Paying due attention to Putnam's Carnapian ideas of conceptual relativity, in particular, we may ask when neopragmatism emerged. (I am not concerned with the term "neopragmatism" but with the emergence of some of the distinctive ideas we associate with it.) There is no trivial answer. Presumably it emerged only in the 1980s when Putnam was busily defending internal realism and noted its connection with pragmatism (and even pointed out, in his 1987 volume The Many Faœs of Realism and elsewhere, that he should have called internal realism "pragmatic realism")? Or perhaps, rather, it emerged in 1979 when Richard Rorty published Philosophy and the M irror of $\mathrm{N}$ ature and shocked his analytic readers by regarding Dewey

\footnotetext{
${ }^{9}$ Richard Rorty's - another key neopragmatist's - more "postmodem" critique of metaphysics is, of course, very different from the logical empiricists' (and from Putnam's), but he shares with Carnap et al. the conviction that in some sense metaphysics fails to make sense.

${ }^{10}$ Among Putnam's many critics, Kenneth Westphal (2003) is particularly explicit in his criticism of this residual Carnapian element in Putnam's internal realist position.
} 
as one of the most important thinkers of the twentieth century? ${ }^{11}$ Or already in 1951 when Quine in "Two Dogmas of Empiricism" exclaimed that our ontological postulations are, "where rational, pragmatic", and claimed to represent a "more thorough pragmatism" than Carnap? ${ }^{12}$

There is hardly any philosophical or historical need to agree about the exact timing of the birth of neopragmatism. One possible answer, however, is that neopragmatism emerged already in 1934 when Carnap formulated his famous Toleranzprinzip in L ogische Syntax der Sprache. ${ }^{13}$ According to this principle, "there is no morality in logic": "In der Logik gibt es keine Moral. Jeder mag seine Logik, d.h. seine Sprachform, aufbauen wie er will. Nur muss er, wenn er mit uns diskutieren will, deutlich angeben, wie er es machen will, synktaktische Bestimmungen geben anstatt philosophischer Erörterungen." (Carnap 1934, 45.) We can, then, freely choose our language, provided that we offer syntactic rules and definitions for its expressions. Later Carnap turned more to semantics, modifying his earlier very restrictive conception of philosophy as the logical syntax of science, but the fundamental idea of tolerating different linguistic frameworks serving different purposes survived the changes in the details of his position. This basic view was, as is well known, elaborated by Carnap in his 1950 essay, "Semantics, Empiricism, and Ontology" - famously criticized by Quine in "Two Dogmas" - but the idea of a plurality of languages through which we categorize reality was there already in 1934. In a sense it was at work already in 1928 in D er logische A ufbau der W elt, in which Carnap had suggested that both phenomenalist and physicalist - that is, autopsychological and heteropsychological (or eigenpsychische and fremdpsychische) - starting points for the construction of scientific language (and, hence, for the "logical construction of the world") are possible, though the phenomenalist one should be preferred (see Carnap 1967; cf. Richardson 1998).

It is easy to characterize Carnap's position as a form of "neopragmatism" by using his own terminology. Carnap distinguishes between "internal" existence questions that are posed within a linguistic framework, concerning the existence of certain entities within that framework, and "external" ones, which concern the adoption of the framework itself. (See Carnap 1950, 209210.) The external questions lack theoretical significance; only internal questions can be answered by means of empirical, scientific research. External questions are resolved only practically; choosing a linguistic framework instead of another is a matter of effectiveness, fruitfulness, and simplicity, among other things - not an empirical or theoretical matter (ibid., 210-212, 219). In

\footnotetext{
11 In addition to Q uine, Rorty is another major philosopher that must be more or less neglected in this essay. 12 "Two Dogmas" is available in Quine (1953); for the famous "more thorough pragmatism" quote, see p. 46. An examination of Quine's and Carnap's complex relation would obviously be beyond the scope of this article. For their correspondence, see Creath (1990). See also, for useful examinations of Quine's relation to Carnap, Neurath, and other leading logical empiricists, Isaacson (2004, especially 229-249), as well as Creath (2007).

13 Or even in 1928 when Morris used the term (see above)?
} 
particular, the problem of the reality of the "world of things" is, metaphysically understood, a mere pseudoproblem (as Carnap had already argued in the A ufbau and other early works): "To be real in the scientific sense means to be an element of the framework; hence this concept cannot be meaningfully applied to the framework itself. Those who raise the question of the reality of the thing world itself have perhaps in mind not a theoretical question as their formulation seems to suggest, but rather a practical question, a matter of a practical decision concerning the structure of our language." (Ibid., 210-211.)

As in 1934, Carnap in 1950 maintains a tolerant view on the plurality of linguistic frameworks. We should, he tells us, "grant to those who work in any special field of investigation the freedom to use any form of expression which seems useful to them", as the work in that field "will sooner or later lead to the elimination of those forms which have no useful function" (ibid., 228). The paper concludes with a famous rule: "L et us be cautious in making assertions and critical in ex amining them, but tolerant in permitting linguistic forms." (Ibid.)

This is essentially the view that Putnam rediscovered and defended in the 1980s when arguing that the world possesses no "ready-made" ontological structure of its own but can be "sliced up" differently by using different conceptual schemes or frameworks - and to which he still, after having returned to metaphysical realism, at least to some extent adheres. Putnam's criticisms of, for instance, Carnap's methodological solipsism (as expressed in the A ufbau) have in no essential way departed from the basic idea of there being a plurality of linguistic frameworks - or conceptual schemes, perspectives, traditions, paradigms (etc.) - through which we categorize reality, frameworks whose critical comparison is a pragmatic matter undecidable by empirical and/or theoretical grounds. Moreover, the attempt to arrive at an empirical or theoretical answer to an external question of existence in an absolute sense, say, to the question whether there "really" are such things as numbers or tables, verges on meaninglessness. In this sense Putnam, even today, to some extent remains a Carnapian - even after his realism has become stronger as a result of his rejection of the epistemic theory of truth that, arguably, was practically indistinguishable from the logical empiricists' verificationism. ${ }^{14}$ It is undeniable that Quine's (1969) later ontological relativity, which gave up the Carnapian distinction between internal and external existence questions, also crucially shaped Putnam's approach to the realism issue. According to Quine and (perhaps) also Putnam, all existence questions have a pragmatic dimension; thus, the division between internal and external questions collapses together with the analytic/synthetic distinction. Yet, Putnam's criticisms of Quine make it clear that he never followed Quine's attack on Carnap to the very end, that is, to the final repudiation of the key

${ }^{14}$ One might perhaps apply the pragmatic maxim to find out what, if any, the key difference between Vienna Circle verificationism and Putnam's 1980s verificationism was. These might come up as practically identical positions. 
Carnapian distinction - even though he agrees with Q uine (and Wittgenstein) rather than Carnap that "[w]hat Carnap is trying to do in 'Semantics, Empiricism and Ontology,' it would seem to both Q uine and Wittgenstein, is to find an external standpoint from which to ondemn ex ternal questions as meaningless" (Putnam 2012, 345). Thus, while Quine (often described as the "killer" of logical positivism) remained, according to Putnam (1990), "the greatest logical positivist", Putnam himself remains faithful to fundamental principles of logical empiricism until this day.

Even though Putnam does not strictly speaking subscribe to Carnapian criteria of meaning or to the view that external questions of existence are literally meaningless, it is legitimate to conclude that whenever Putnam defends a position close to, say, James's or Dewey's pragmatism (or pluralism), he does this, as we may say, in (and not despite) his Carnapian mode. Neopragmatism more generally - at least Putnam's and Rorty's - is primarily a language-oriented form of pragmatism in contrast to the more experience-based classical pragmatism (cf. Hildebrand 2003). This also indicates how strongly "Carnapian" (rather than, say, "D eweyan") Putnam's neopragmatist position on realism vs. antirealism is.

However, we should take seriously the Kantian elements of Putnamian neopragmatism, and of logical empiricism, even though this cannot be done here in any detail. It is perfectly possible for the neopragmatist to admit that our ontologies are humanly constructed in a transœendental sense while the objects and processes of the world we postulate within such ontological theorizing remain empirically (and, hence, factually, causally, and otherwise) independent of us and our theories. Thus, empirical ontological commitments internal to our frameworks have, and need, an extra-human standard (viz., the way things are, when seen through that framework), while the adoption of the framework itself is a kind of transœndental activity only pragmatically decidable - or criticizable. This idea, if further developed, comes close to Lewis's (1929) "pragmatic a priori". Kantian apriorism, and particularly transcendental idealism, however, are nothing that Putnam would be willing to embrace. Putnam points out repeatedly that we should not confuse "making up" our notions with "making up" real systems in the world, unless we want to "slide into idealism", which is "a bad thing to slide into" (Putnam 2012, 64). Now, this is itself a Carnapian distinction, echoing the external vs. internal contrast again. ${ }^{15}$ It is, arguably, a distinction that the classical pragmatists already cast a critical eye on while preserving (in my view) it in a pragmatic form. Something like the transcendental vs. empirical distinction must be made in order for Putnam's own realism-with-conceptual-relativity to succeed.

${ }^{15} \mathrm{~K}$ ant (1781/ 1787) himself would not recommend confusing the two, either, because the things in themselves, in his view, clearly are not "made up". 
In brief, Putnam's Carnapianism comes down to a deep-seated fear of metaphysics. Even if pragmatically needed, metaphysics is to be avoided. Putnam does not, then, seem to be sufficiently receptive to the pragmatist idea (arguably at work in James, among others) that metaphysics should not be a priori dismissed but should itself be pragmatically elaborated and ex amined; its true practice-involving core ought to be traced out by employing the pragmatic maxim in an ethically engaging way (Pihlström 2009). This is understandable, as logical empiricism generally was a strongly anti-metaphysical movement. In A.J. Ayer's memorable phrase, "no statement which refers to a 'reality' transcending the limits of all possible sense-experience can possibly have any literal significance" (Ayer 1946, 46). Philosophy must be sharply distinguished from age-old metaphysical speculation (ibid., 55ff.); metaphysics can only have poetic, aesthetic, moral, emotive, or expressive value - instead of any cognitive value (ibid., 59-61). In particular, Ayer argues that the problem of realism vs. idealism, metaphysically construed, is "fictitious", devoid of any cognitive or theoretical content (ibid., 54-55, 182-193). In a similar vein, Moritz Schlick rejected the realism issue as meaningless metaphysics: "The denial of the existence of a transcendent external world would be just as much a metaphysical proposition as its assertion; the consistent empiricist does not therefore deny the transcendent, but declares both its denial and its affirmation to be equally devoid of meaning." (Schlick 1932-33, 54.) We can easily find a host of similar statements not only from Carnap's writings but also, by extension, from Putnam's.

\section{Science and metaphysics: Eino Kaila's logical empiricism revisited}

Although I speculated about neopragmatism's possible emergence in relation to the Carnapian principle of tolerance, it could be argued that neopragmatism emerged, instead of 1934, already in 1929-30 when Ludwig Wittgenstein returned to work on philosophical problems after the decade he had, following the publication of the Tractatus, spent as a teacher in rural Austria. Wittgenstein's relation to pragmatism is a complex issue not to be explored here (Pihlström 2012a). However, we may explore some less well known cases. I will, thus, offer an excursion to the views of an internationally relatively marginal twentieth-century philosopher. One of the somewhat neglected logical empiricists, the Finnish philosopher Eino Kaila, ${ }^{16}$ was an early

\footnotetext{
${ }^{16}$ Kaila (1890-1958) was one of the most important Finnish philosophers of the twentieth century. He never gained the international recognition that his pupils Georg Henrik von Wright and Jaakko Hintikka enjoyed; indeed, these philosophers, trained by Kaila, as well as their students, were largely responsible for the way in which Finnish philosophy emerged as a significant part of the international tradition of analytic philosophy grounded in logical empiricism. Yet, it is no exaggeration to say that Kaila brought scientifically-oriented analytic philosophy to Finland in the late 1920-30s, with close contacts with leading logical empiricists such as Carnap, Reichenbach, and Schlick.
} 
admirer of James. In his 1912 essay on James, now available as an English translation, ${ }^{17}$ Kaila discussed James's pragmatism very sympathetically. He was never a pragmatism scholar or a follower of James, but it is an intriguing historical fact that he was, at an early stage, seriously interested in and influenced by James's pragmatism. This early encounter with pragmatism still shows in his logical empiricist works. In the late 1920s, Kaila became an external member of the Vienna Circle and may even have coined the phrase, "logical empiricism" (he never referred to his own thought as "logical positivism"). ${ }^{18}$ If we regard the dialogue with logical empiricism as crucial to the development of neopragmatism, we might see the latter as beginning to emerge when Kaila's views started to take shape in 1912 - that is, when this future logical empiricist drew inspiration from James's "will to believe".

Pragmatism was, for the young Kaila, a promising perspective on the controversy between science and religion. This issue was one of his great interests, presumably partly because of his family background.${ }^{19} \mathrm{Kaila}$ took the scientific challenge to religion seriously, to the extent that he ended up as a major critic of traditional religion; yet, while he firmly rejected dogmatic religious creeds, he never completely abandoned the "romantic" tendencies of metaphysical and religious thinking. In the 1912 essay on James, Kaila was still relatively sympathetic to religion. He emphasizes the significance of James's pragmatism as a revolutionary approach in philosophy, adopting the "agent's perspective" instead of the perspective of a mere passive spectator. He views pragmatism as an answer to the problem of how a person who refuses to give up reason or make easy intellectual compromises can deal with her/ his religious needs, or the need for a higher "spiritual" content and meaning in life. Kaila not only endorses James's "will to believe" but explicates this idea in an illuminating way. A religious or "idealist" hypothesis conceming the significance of human life in relation to a more spiritual and "eternal" universe can, he maintains, be entertained at the individual believer's own risk, and it is better to act on such an insecure belief than to fall into skeptical inactivity.

Later, as a logical empiricist, Kaila was "officially" sharply critical of religion. The mature Kaila of the 1930-40s was primarily a philosopher of science, introducing modern logical and epistemological ideas in Finland. Metaphysical and religious statements, he argued, fail to meet the criteria of meaningfulness set by the philosophers of the Vienna Circle. Kaila's criticism

${ }^{17}$ His essay, "William James - Amerikan filosofi", originally published in Finnish in U usi Suometar (a leading conservative newspaper) in September 1912, was recently made available as an English translation by Heikki A. Kovalainen in the Transactions of the Charles S. Peirce Sodety (2011). This essay is discussed in detail in Pihlström (2012b).

${ }^{18}$ For secondary literature on Kaila, see Niiniluoto et al. (1992) and Niiniluoto and Pihlström (2012). Kaila's key writings have been translated into English in Kaila (1979).

${ }^{19}$ His father, Erkki Kaila (who wrote a textbook on the history of philosophy in 1914), later became the arch-bishop of the Finnish Lutheran Church, and there were other important clergymen in the family as well. 
of metaphysics culminates in the "principle of testability" (a variation of Carnap's and Reichenbach's related principles): any statement about reality must be constructed so that a set of empirical statements (its "real content") can be derived from it; the truth or probability of the statement can only be assessed on the grounds of its real content. ${ }^{20}$ While metaphysical and religious views are not scientifically acceptable in this sense, they may, as Kaila suggests in his psychological magnus opus on personality (1934), function as "spiritual insurance companies" defending us against various threats of life, especially the fear of death.

Accordingly, Kaila pragmatistically argued that religious and metaphysical worldviews may be "practically testable", even if they cannot meet the rigorous requirement of empirical testability applied to scientific theories because of their minimal "real content". What Kaila calls practical testability has nothing to do with the real content of beliefs; rather, it focuses on their results in practical action and ways of life. Religious and metaphysical ideas may serve as motives for action, and they may even be accepted insofar as their practical results are acceptable (Kaila 1943). Religions may be acceptable as "systems of action", not as systems of beliefs. Their "practical truth" must be distinguished from "truth in the proper sense", which is the concern of scientific theories (ibid., 190). Kaila thus proposes to apply, "without restrictions, the way of thinking called pragmatism", to metaphysical "explanations of the world", pointing out that pragmatism leads to contradictions when applied to theoretical conceptions of the world but may be legitimately applied to "views of life": "From their fruits you shall know them. Those views of life are good which have good fruits." (Ibid., 189.)

Echoes from the early James essay can be heard here, right in the middle of Kaila's logical-empiricist period. There are, more generally, important parallels between Kaila and James, even if we consider Kaila's mature work. Both were - especially at an early career-stage psychologists as much as philosophers. Moreover, both were extremely broad in their intellectual scopes, combining scientific perspectives with "romantic" sentiments focusing, rather, on art and religion. Indeed, Kaila's late work, Syvähenk inen elämä (D eep-Mental Life, 1943), which I just cited, is explicitly a dialogue between a scientifically-minded and a romantically-oriented character with process-metaphysical ideas. In Kaila's case, perhaps more than James's, the scientific "ego" was stronger. However, even in that late work, James's voice can be heard in the "romantic" character - as Kaila admits both in the preface and in the dialogue itself (ibid., 8, 202). Indeed, the romantic character of the dialogue points out, as James might have done, that theoretical and practical testability may in the end collapse into one another, especially when we are dealing with "theories about the spiritual"; Kaila even here follows James's suggestion that G od may need our

20 This principle is spelled out in more detail in the essays (from the early 1930s) translated in Kaila (1979). 
faith as a support of His existence (ibid., 192-193). This is a suggestion that the "winner" of the dialogue, Kaila's scientific ego, firmly rejects, but one can hardly deny that Kaila was internally tormented by these diverging ideas, partly as a result of his early admiration of James. He may have seen the identification of theoretical and practical testability as a temptation of his own philosophical temperament (to employ a Jamesian concept), a temptation he succeeded in resisting. The two voices of the dialogue are both genuinely his own, while the scientific one prevails.

The tension we have located in Kaila serves as a reminder of the fact that logical empiricism and pragmatism may also function as different "voices" within a single philosopher. Arguably, this is true about Putnam, too. It may even - before the emergence of logical empiricism - have been true about James, who was both an empirical scientist and a "romantic", religiously inclined thinker. At a meta-level, we should, I believe, cherish a pragmatic attitude that celebrates, instead of seeking to eliminate, this enriching dialogue of potentially conflicting voices. The Carnapian dimensions of neopragmatism are also just one voice, not the final truth about neopragmatism.

Furthermore, the Kaila case - like Putnam's case later - should lead us to appreciate the way in which both pragmatism and logical empiricism were (and are) concerned with the issue of scientific realism, on the one hand, and the debate on the relation between science and other human practioes, on the other. Logical empiricism, as is well known, collapsed (to the extent that it ever did collapse) partly as a result of the rise of scientific realism due to such philosophers as Karl Popper and Wilfrid Sellars. Pragmatism, in turn, finds itself in constant struggle to keep a balance between realism, empiricism, and (Kantian-like, Kuhnian) constructivism, and in this struggle the possible dominance of science over other human practices, such as art, morality, religion, or everyday life, is continuously on the agenda. The problem of scientific realism seems to unite these concerns, because they ultimately come back to the question of whether science offers us a picture of the world that is "first-rate" or ontologically prior in comparison to other - merely "second-rate" - accounts of reality. The dialogue between pragmatism and whatever remains from logical empiricism also needs to be continued by focusing on these issues, that is, scientific realism (in relation to empiricism and constructivism) and the place of science in human culture (in relation to other human practices). These issues are in the end intimately connected, because the stronger and the more exclusively scientistic one's realism becomes, the less one is able to take other practices ontologically seriously. Putnam's work on realism has been constantly alarmed by these scientistic threats and sought to overcome them while not giving up realism altogether. 
This takes us to Kaila again. The point of bringing him into this discussion was not just to note that he was one of the later logical empiricists who read James in the 1910s (and here he wasn't alone, as James was well known in Europe). It is vital to observe that he never regarded philosophical problems, especially the "problem of reality" or realism as meaningless pseudoproblems. His philosophy was closer to the pragmatic, scientifically sensitive metaphysical approach that the classical pragmatists favored - at least at the meta-level if not in details. $\mathrm{He}$ resisted metaphysics and wanted philosophical thought to be "deep and clear" instead of "shallow and muddled" (as he considered the metaphysics of German idealism and especially Heidegger's philosophy to be), but he was nevertheless a "synthetic" (rather than analytic) philosopher of nature (rather than of language). I am not saying that we should endorse his views, but his synthetic approach is at a meta-level relevant for the pragmatist today, also because of its ability to accommodate conflicting "voices".

Even when defending an empiricist criterion of testability, Kaila was ultimately interested in how we are able to formulate meaningful scientific statements about reality. Thus, implicitly following Peircean pragmatism, he regarded science as a process of examining "real things", not just a process of, say, systematizing observations or of predicting and controlling phenomena. Indeed, philosophy itself in the end concerns the ways we are related to reality; it is not merely concerned with the meanings of language. Coming close to Putnam's later internal realism, Kaila spoke, in a posthumous paper, "The Perceptual and Conceptual Components of Everyday Experience" (Kaila 1979, chapter 4), about the "relativization of reality". He argues that there is no sharp, unequivocal contrast between the "real" and the "unreal"; rather, conditions for calling a thing "real" can be arranged into a sort of logical hierarchy. In particular, he distinguishes between perceptual objects, physical objects of everyday experience, and physico-scientific objects investigated in physical science. As one proceeds from perceptual to scientific objects, the degree of invariance - stability, immutability - and the degree of conceptualization of the relevant objects increase. The difference between the perceptual and the conceptual components of experience is a relative difference, not an absolute one. Yet, the more invariant the objects (or the "reality" examined) are, and the more general the relevant invariances are, the more the objects are conceptualized. (Ibid., chapter 4, sections 9-10.) What is real is not independent of the way in which it is conceptualized by us; there is no unconceptualized reality. Kaila's relativization of reality is, however, exactly this: a relativization of reality, not just language or conceptual schemes.

Clearly, science is absolutely central for Kaila in approaching the "riddle of reality" (see ibid., and Nïniluoto 1992). His position resembles scientific realism in the sense that it is 
science that is taken to get us closer to reality. The metaphysical status of the real remains a subtle issue in Kaila, though - and as I already suggested, this subtlety is readily comparable to Putnam's worries about realism. ${ }^{21}$ Both Putnam and Kaila seriously confront the problem of reconciling the realist view that the objects we experience and speak about, in scientific and everyday contexts, exist independently of us with the pragmatist (or "internal realist") view that those objects are not unconceptualized or "ready-made" independently of our conceptual interventions but are always already conceptualized by us in order for them to be able to be any objects at all. The analogy to Carnapian linguistic frameworks as something that enable us to identify certain existing objects should be obvious; for both Kaila and Putnam, the need to reconcile realism with conceptual relativity may have become a central, life-long philosophical concern as a result of their encounters with Carnap and logical empiricism. I am not conceived that any of these philosophers has been able to offer a completely satisfactory solution to this problem of reality. But they all prepared the ground for neopragmatist contributions.

Finally, Kaila's and Putnam's views on values are also interestingly comparable, as they again reveal their somewhat troublesome reactions to logical empiricism. Neither philosopher offers any full-blown metaphysical theory of values as elements of reality or (in Putnam's case) of the fact-value entanglement; rather, the inseparability of fact and value is accounted for linguistically and conceptually by Putnam, as an inseparability of factual and evaluative statements and concepts, while Kaila's "official" position is an emotivist and subjectivist theory of values along the lines of logical empiricism. However, both also seem to maintain these quasi-logical-empiricist ideas partly against their own will. Kaila regarded spirituality or "deep-mentality" (syvähenkisyys) as the highest value of human life, realized in science and art, for instance, and this seems to need a value-realist backing (which, perhaps, could be available in the kind of romantic philosophy of nature he was inclined toward despite his logical empiricism); Putnam, in turn, has repeatedly reminded us that values, after all, are not "queer" objects (presumably also because they are no objects at all) and that science and ethics are equally realistic and cognitive practices. In a revealing passage, Putnam (1990) says that if he were a metaphysician (implying, that is, that he is not), he would construe the world as a collection of "permanent possibilities of obligation". Again, we see the tension between

${ }^{21}$ Niiniluoto $(1992,109)$ suggests that Kaila's view on realism was in an interesting way close to Sellars's distinction between the scientific image and the manifest image. Everyday objects could be regarded as epistemologically prior but ontologically secondary to scientific objects, that is, to the scientific image of the world. Niiniluoto continues with a comparison to Putnam: "Kaila was not a 'metaphysical realist' in Putnam's sense: the existing objects are not 'ready made' waiting for us, since the more real objects are also more conceptualized. So in the end Kaila may have been a kind of 'internal realist'. But, in spite of his talk about the 'relativization of reality', he was not a relativist. There is a sense in which physical and scientific objects are objective, independent of us and our perceptions." (Ibid., 112-113.) This picture of Kaila on realism, science, and metaphysics is supplemented in several essays in Niiniluoto and Pihlström (2012). 
metaphysics and anti-metaphysics at work in Kaila's and Putnam's accounts of value. Philosophy, for both, is ultimately about "ultimate questions", and clearly logical empiricism as such is insufficient to deal with them, though healthy doses of logic and empiricism may be necessary for us to pursue them responsibly.

\section{Conclusion}

Contemporary pragmatism and neopragmatism should recognize not only their roots at Harvard (e.g., Peirce, James, Lewis) and Columbia (e.g., Dewey, Nagel) but also their logical-empiricist Viennese background - and should do so in many areas: in metaphysics, anti-metaphysics, epistemology, philosophy of science, ethics, and philosophy of religion, among others. This essay has partly focused on Putnam's neopragmatism, which is an illuminating case because of its indebtedness to Carnap's ideas of "tolerance" and linguistic frameworks; however, the moral of the discussion is more general. Pragmatism is at its best when it flexibly engages in collaboration with other philosophical orientations - including not only analytic philosophy but also phenomenology, hermeneutics, critical theory, etc. - while maintaining its own identity. Forgotten figures of the logical empiricist movement, such as Kaila, and their reception of pragmatism, should also be explored more deeply. Pragmatism, generally, ought to speak - and also listen ${ }^{22}$ - not only to the well-known philosophical orientations today, such as analytic philosophy or phenomenology, but also to the marginalized and eclipsed ones, whether or not pragmatism itself was ever truly eclipsed by logical empiricism or analytic philosophy.

A certain kind of focus on philosophical anthropology (so to speak) ultimately distinguishes pragmatism from logical empiricism at least in its standard forms. For pragmatism, the human being is at the center of philosophical inquiry; it is more important to understand human experience in its richness, individual and communal, than it is to get clear about the structure of scientific theories, for instance (though these are by no means conflicting pursuits). While the two philosophies share a common interest in the prospects of scientific realism, as explained, the contexts within which this problem is approached differ perhaps more deeply than is sometimes acknowledged - and this may result from the diverging approaches to the question concerning the place of science in human culture. A true revolution in philosophy would offer a new response to that question, maintaining both the value of science and the value of human

${ }^{22}$ Cf. David Hildebrand's apt remark on pragmatism as a "listening philosophy" (in conversation, May 2013). 
freedom and constructive interpretation in our world-engagement. But that can only be a revolution yet to come, not a revolution to be found in our philosophical past. ${ }^{23}$

\section{References}

Ayer, A.J. (1946), L anguage, Truth and L ogic. Harmondsworth: Penguin, 1986.

Carnap, Rudolf (1934), L ogische Syntax der Sprache. Wien: Springer.

--- (1950), "Empiricism, Semantics, and Ontology", in Leonard Linsky (ed.), Semantics and the Philosophy of L anguage. Urbana: University of Illinois Press, 1952, 208-228. (O riginally published in Revue Internationale de Philosophie 11.)

--- (1963), "Replies and Systematic Expositions", in Paul Arthur Schilpp (ed.), The Philosophy of Rudolf Carnap. La Salle, IL: O pen Court, 859-1013.

--- (1967), The L ogical Structure of the W orld \& Pseudoproblems in Philosophy, trans. Rolf A. George. Berkeley and Los Angeles: University of California Press. (O riginally published as D er logische A ufbau der W elt, 1928.)

Creath, Richard (ed.) (1990), D ear Carnap, D ear V an: The Q uine - Carnap Correspondence and Related W ork. Berkeley: University of California Press.

--- (2007), "Vienna, the City of Quine's D reams", in Richardon and Uebel (2007), 332-345.

Dewey, John (1938), "Unity of Science as a Social Problem”, International E ncydopedia of Unified Scienœ 1:1, 29-38.

--- (1939), "Theory of Valuation", International E ncydopedia of U nified Scienœ 2:4. Chicago: University of Chicago Press.

Friedman, Michael (2001), D ynamics of Reason. Stanford, CA: CSLI Publications.

--- (2003), "Kuhn and Logical Empiricism", in Thomas Nickels (ed.), Thomas Kuhn. Cambridge: Cambridge University Press, 19-44.

--- (2007), "Coordination, Constitution, and Convention: The Evolution of the A Priori in Logical Empiricism", in Richardson and Uebel (2007), 91-116.

Giere, Ronald N. and Richardson, Alan W. (eds.) (1996), Origins of Logical E mpiricism. Minnesota Studies in the Philosophy of Science 16. Minneapolis and London: University of Minnesota Press.

Hickman, Lary (2007), Pragmatism as Post-Postmodernism: L essons from D ewey. New Y ork: Fordham University Press.

Hildebrand, David (2003), Beyond Realism and A ntirealism: D ewey and the N eopragmatists. Nashville, TN: Vanderbilt University Press.

Holton, Gerhard (1993), "From the Vienna Circle to Harvard Square: The Americanization of a European World Conception", in Friedrich Stadler (ed.), Scientific Philosophy: Origins and D evelopments. D ordrecht: Kluwer, 47-73.

Isaacson, D aniel (2004), "Q uine and Logical Positivism", in Roger F. Gibson (ed.), The C ambridge C ompanion to Q uine. Cambridge: Cambridge University Press, 214-269.

James, William (1907), Pragmatism: A N ew N ame for Some Old W ays of Thinking. Eds. Frederick H. Burkhardt, Fredson Bowers, and Ignas K. Skrupskelis. Cambridge, MA and London: Harvard University Press, 1975.

Kaila, Eino (1912), "William James, Philosopher of America", trans. Heikki A. Kovalainen, Transadions of the Charles S. Peirce Society 47, 2011. (O riginally published in U usi Suometar, September 1912.)

--- (1934), Persoonallisuus [Personality]. O tava, Helsinki.

--- (1943), Syvähenkinen elämä [The D eep-Mental Life]. O tava, Helsinki (3rd ed., 1986).

--- (1979), Reality and E x perience. D ordrecht: D. Reidel.

23 I should like to warmly thank Maria Baghramian and Sarin Marchetti for kindly inviting me to present a version of this paper in the Philosophical Revolutions conference in Dublin (June, 2013) and to contribute this essay to the volume. Another version of this material was presented at a conference on logical empiricism and pragmatism in Vienna (November, 2013); the forthcoming (longer) version of that paper has some affinities with the present essay, while these remain two separate articles. 
Kant, Immanuel (1781/ 1787), Kritik der reinen V ernunft, ed. Raymund Schmidt. Hamburg: Felix Meiner, 1990.

Koskinen, Heikki J. (2004), From a Metaphilosophiøal Point of V iew: A Study of W.V. Quine's N aturalism. Acta Philosophica Fennica. Helsinki: The Philosophical Society of Finland.

--- and Pihlström, Sami (2006), "Q uine and Pragmatism”, T ransadions of the Charles S. Peirce Sodidy 42.

Lewis, C.I. (1929), "A Pragmatic Conception of the A Priori”, The Journal of Philosophy 20, 169-177.

Limbeck-Lilienau, Christoph (2012), "Carnap's Encounter with Pragmatism”, in Richard Creath (ed.), Rudolf Carnap and the L egacy of L ogical E mpiricism. Vienna Circle Institute Y earbook 16. D ordrecht: Springer, 89-110.

Misak, Cheryl (ed.) (2007), N ew Pragmatists. Oxford: Oxford University Press.

--- (2013), The A merican Pragmatists. Oxford: Oxford University Press.

Mormann, Thomas (2012), "Toward a Theory of the Pragmatic A Priori: From Carnap to Lewis and Beyond", in Richard Creath (ed.), Rudolf Carnap and the Legacy of L ogical E mpiricism. Vienna Circle Institute Yearbook 16. Dordrecht: Springer, 113-132.

Morris, Charles (1928), "Neopragmatism and the Ways of Knowing", The M onist 38, 494-510.

--- (1934), "Pragmatism and Metaphysics", The Philosophical Review 43:6, 149-164.

--- (1937), "The Concept of Meaning in Pragmatism and Logical Positivism", in Amelie Rorty (ed.), Pragmatic Philosophy: A n A nthology. Garden City, NY : D oubleday \& Co., 1966, 374-381.

--- (1938), "Peirce, Mead, and Pragmatism", The Philosophical Review 47, 109-127.

--- (1963), "Pragmatism and Logical Empiricism", in Paul Arthur Schilpp (ed.), The Philosophy of Rudolf Carnap. La Salle, IL: O pen Court, 87-98.

Nagel, Ernest (1940), "Charles S. Peirce, Pioneer of Modern Empiricism", in Emest Nagel, Sovereign Reasons. Glencoe, IL: The Free Press, 89-100.

Niiniluoto, Ilkka (1992), "Eino Kaila and Scientific Realism”, in Niiniluoto et al. (1992), pp. 102-116.

--- (1999), Critical Scientific Realism. Oxford: Oxford University Press.

---, Sintonen, Matti, and von Wright, Georg Henrik (eds.) (1992), E ino Kaila and L ogical E mpiricism. Acta Philosophica

Fennica 52. Helsinki: The Philosophical Society of Finland.

--- and Pihlström, Sami (eds.) (2012), Reappraisals of E ino Kaila's Philosophy. Acta Philosophica Fennica 89. Helsinki:

The Philosophical Society of Finland.

Pihlström, Sami (2003), N aturalizing the Transcendental: A Pragmatic V iew. Amherst, NY: Prometheus/ Humanity Books.

--- (2006), "Putnam's Conception of Ontology", C ontemporary Pragmatism 3.

--- (2008), "How (Not) to Write the History of Pragmatist Philosophy of Science?", Perspetives on Scienee 16, 26-69.

--- (2009), Pragmatist M etaphysics: A n E ssay on the E thical G rounds of O ntology. London: Continuum.

--- (2010), "E mergence or Continuity? Toward a Pragmatist Metaphysics of the Fact-Value Entanglement", Journal of

Philosophical Research 35.

--- (ed.) (2011), The Continuum Companion to Pragmatism. London: Continuum.

--- (2012), "A New Look at Wittgenstein and Pragmatism", E uropean Journal of Pragmatism and A merican Philosophy 4:2, www.journalofpragmatism.eu.

--- (2012b), "Eino Kaila on Pragmatism and Religion", in Niiniluoto and Pihlström (2012).

--- (2013), Pragmatic Pluralism and the Problem of G od. New Y ork: Fordham University Press.

Putnam, Hilary (1981), Reason, Truth and H istory. Cambridge: Cambridge University Press.

--- (1987), The M any Faoes of Realism. La Salle, IL: O pen Court.

--- (1990), Realism with a H uman Faœ. Ed. James Conant. Cambridge, MA and London: Harvard University Press.

--- (1992), Renewing Philosophy. Cambridge, MA and London: Harvard University Press.

--- (1994), W ords and L ife. E d. James Conant. Cambridge, MA and London: Harvard University Press.

--- (1995), Pragmatism: A n 0 pen Q uestion. O xford and Cambridge, MA: Blackwell.

--- (2002), The Collapse of the F adt/ V alue D ichotomy and Other E ssays. Cambridge, MA and London: Harvard University Press.

--- (2004), E thics without O ntology. Cambridge, MA and London: Harvard University Press.

--- (2006), "Responses", C ontemporary Pragmatism 3.

--- (2012), Philosophy in an A ge of Scienœ. Eds. Mario De Caro and David Macarthur. Cambridge, MA and London: Harvard University Press. 
Quine, W.V. (1953), From a L ogical Point of V iew. Cambridge, MA: Harvard University Press, rev. ed. 1980. ---(1969), 0 ntological Relativity and 0 ther E ssays. New Y ork: Columbia University Press.

Ramsey, Frank Plumpton (1927), "Facts and Propositions", in F.P. Ramsey, Philosophical Papers, ed. D.H. Mellor. Cambridge: Cambridge University Press, 1990, 34-51.

Reichenbach, Hans (1939), "D ewey's Theory of Science", in Paul Arthur Schilpp (ed.), The Philosophy of John D ewey. La Salle, IL: O pen Court, 3rd ed., 1989, 159-192.

Richardson, Alan W. (1998), Carnap's Construction of the W orld: The A ufbau and the E mergence of L ogical E mpiriasm. Cambridge: Cambridge University Press.

--- (2007), “That Sort of Everyday Image of Logical Positivism': Thomas Kuhn and the Decline of Logical Empiricist Philosophy of Science", in Richardson and Uebel (2007), 346-370.

--- and Uebel, Thomas (eds.) (2007), The Cambridge Companion to L ogical E mpiricism. Cambridge: Cambridge University Press.

Rorty, Richard (1979), Philosophy and the Mirror of N ature. Princeton, NJ: Princeton University Press.

Schlick, Moritz (1932-33), "Positivism and Realism", trans. Peter Heath. In Richard Boyd et al. (eds.), The Philosophy of Scienœ. Cambridge, MA and London: The MIT Press, 1991, 37-55.

Shook, John R. (1998), Pragmatism: A n A nnotated Bibliography 1898-1940. Amsterdam and Atlanta: Rodopi.

Sinclair, Robert (2011), "Morton White's Moral Pragmatism", Cognitio 12, 143-155.

--- (2013), "Q uine and Conceptual Pragmatism", T ransadions of the Charles S. Peirœ Sodety 49.

Uebel, Thomas (1992), Overcoming L ogical Positivism from Within: The E mergence of $\mathrm{N}$ eurath's $\mathrm{N}$ aturalism in the V ienna Cirde's Protoool Sentence D ebate. Atlanta: Rodopi.

--- (1996), "The Enlightenment Ambition of E pistemic Utopianism: Otto Neurath's Theory of Science in Historical Perspective", in Giere and Richardson (eds.), 91-112.

Westphal, Kenneth R. (2003), “Can Pragmatic Realists Argue Transcendentally?”, in John R. Shook (ed.), Pragmatic $\mathrm{N}$ aturalism and Realism. Amherst, NY: Prometheus. 